\title{
The Law of Criminal Informant in Ethiopia
}

\author{
Alemu Meheretu Negash*
}

\begin{abstract}
Many jurisdictions use criminal informants -suspects or defendants who provide evidence in return to a charge or a sentence benefit- to investigate and prosecute mainly organized crimes. Ethiopia has also embraced this investigation and prosecution tool with respect to some selected crimes. This article examines and explicates the legal framework on criminal informant in the context of four proclamations governing corruption, terrorism, trafficking and smuggling in persons, and witness and whistle blowers protection. I argue that the law suffers considerable limitations and gaps in articulating complete, clear and coherent standards for informant selection, and consistent concessions and benefits, as well as in terms of instituting adequate guarantees and meaningful enforcement mechanisms to protect defendants against the blemishes of the informant system.
\end{abstract}

\section{Key terms}

Criminal informant $\cdot$ Evidence $\cdot$ Substantial evidence $\cdot$ Concessions $\cdot$ Safeguards Witness protection $\cdot$ Ethiopia.

DOI http://dx.doi.org/10.4314/mlr.v13i3.5

This article is licensed under a Creative Commons Attribution-NonCommercialNoDerivs (CC BY-NC-ND)

\section{Suggested citation:}

Negash, Alemu Meheretu (2019), 'The Law of Criminal Informant in Ethiopia', Mizan Law Review, Vol. 13, No. 3, pp. 442-471.

\section{Introduction}

Jurisdictions employ various investigative techniques including use of informants, physical and/or electronic surveillance, informant protection schemes and undercover agents to fight crimes and criminals, notably organized crimes. ${ }^{1}$ This article deals with criminal informants who provide evidence

\footnotetext{
- Alemu Meheretu Negash, PhD, Asst. Professor of Law, Jimma University School of Law; Email: Alemeheret@gmail.com. ORCID: https://orcid.org/0000-0001-9968-7911 Acronyms:

ECJ Ethiopian Criminal Justice

FDRE Federal Democratic Republic of Ethiopia

${ }^{1}$ Thomas Gobar et al (2010), Community Effects of Law Enforcement Countermeasures against Organized Crime: A retrospective Analysis, Report No 006, available at: $<$ https://www.publicsafety.gc.ca>, p. 4. (Accessed on 25 Feb 2018)
} 
against co-defendants/participants in exchange for some concessions: sentence and/or charge reduction or total exemption from criminal liability, often known as immunity.

Many jurisdictions use criminal informants as a tool of investigation and garnering relevant evidence in a criminal participation so that criminals face justice. ${ }^{2}$ Criminal informants are also applied to thwart crimes. ${ }^{3}$ Conventionally, criminal informants are employed in organized crimes to investigate and prosecute those suspects up in the ladder of a criminal activity who normally operate through intermediaries. ${ }^{4}$ International Conventions recognize and encourage states to use criminal informants in the investigation and prosecution of transnational organized crimes and crimes of corruption. ${ }^{5}$ The major rationale for criminal informant use in organized crimes rests mainly on the assumption that "the most culpable and dangerous criminals rarely do the 'dirty job'..."; instead they often control and guide others to do it. ${ }^{6}$ Thus, allowing "low-tier criminals to flip and turn informants seems to be a potentially key channel to fight organized crimes". ${ }^{7}$

In Ethiopia, criminal informant use has found its place mainly through four proclamations: the Anti-Corruption Proclamation ${ }^{8}$, Anti-terrorism Proclamation ${ }^{9}$, Anti- trafficking and smuggling Proclamation ${ }^{10}$ and Witness and whistleblowers

2 This applies for example in such jurisdictions as diverse as Italy, Germany, USA, Netherlands and UK at varying degrees. See Nicholas Fyfe and James Sheptycki (2006), 'International Trends in the Facilitation of Witness Cooperation in Organized Crimes', European Journal of Criminology Vol. 3, No. 3, pp. 336-38.

${ }^{3}$ Peter J. Tak (1997), 'Deals with Criminals: Supergrasses, Crown Witnesses and Pentiti', European Journal of Crime, Criminal Law and Criminal Justice, Vol.5, No.2, p. 18.

${ }^{4}$ Antonio Acconcia, et al (2014), 'Accomplice Testimony and Organized crimes: Theory and Evidence from Italy', Scand. J. of Economics, Vol.116, No. 4, pp. 1116-1159.

${ }^{5}$ See Article 37 of UN Convention Against Corruption and Article 26 of UN Convention Against Transnational Organized Crimes; where both instruments recognize the use of sentence mitigation or immunity in exchange of the criminal informants assistance in the investigation and prosecution of crimes in question. See also Article 5(5) of AU Convention on Preventing and Combating Corruption where although not so explicit on rewarding informants, States parties undertake the obligation to "adopt legislative and other measures to protect informants and witnesses in corruption cases..." which could include exemption from criminal prosecution.

${ }^{6}$ Antonio Acconcia, et al (2014), supra note 4, p.1117.

${ }^{7}$ Ibid.

${ }^{8}$ Article 43(1), The Revised Anti-Corruption Special Procedure and Rules of Evidence Proclamation No. 434/2005.

${ }^{9}$ Article 33, The Anti-terrorism Proclamation No. 652/2009.

${ }^{10}$ Article 23, The Prevention and Suppression of Trafficking in Persons and Smuggling of Migrants Proclamation No 909/2015. 
protection Proclamation. ${ }^{11}$ It is also recognized under the newly adopted FDRE Criminal Justice Policy. The Policy explicitly allows the use of criminal informant testimony in 'organized crimes', corruption, terrorism, and complex crimes. $^{12}$ The above legal and policy frameworks for informant use have remained unexplored. Very little is known or no research has been conducted on how informant use is regulated under Ethiopian law, notably the legal framework on the standards to select criminal informants, the nature of concessions and benefits involved, enforcement mechanisms, and the safeguards put in place for defendants. This article investigates the extent to which the legal framework fares in regulating criminal informant use. To this end, it analyses laws, policy documents, and relevant literature on the subject matter.

The first section of this article sets out the scene by briefly discussing the meaning and nature of criminal informants. The second section outlines the rationales of criminal informants use in the Ethiopian setting. The third section examines the laws governing criminal informant use followed by the final section that forwards concluding remarks.

\section{Meaning and Nature of Criminal Informants}

Criminal informants are suspects or defendants who provide information or evidence in exchange for an inducement or benefit. ${ }^{13}$ This may include accomplices, co-defendants, and co-conspirators who seek cooperation deals with prosecutors in order to reduce or avoid their criminal exposure. ${ }^{14}$ They are distinguished from law-abiding persons who supply information to law enforcement organs and often regarded as source of information: victims, whistle-blowers, citizens, investigators etc. The form of assistance criminal informants deliver to the system could range from providing information that enables investigation to testifying against fellow co-offenders. Hence, they are sometimes called cooperating witnesses, informant witnesses or incentivized witnesses. The benefits criminal informants procure span from simple financial gains to sentence or charge concessions or total exemption from prosecution. ${ }^{15}$

Although criminal informants may take a variety of forms, this article focuses on criminal informants who supply information/evidence in relation to a

\footnotetext{
${ }^{11}$ Article 3, Protection of Witnesses and Whistle-blowers of Criminal Offences Proclamation No.699/2010.

${ }^{12}$ See FDRE (2011), The Criminal Justice Policy of Ethiopia, pp. 22-23.

${ }^{13}$ Alexandra Natapoff (2009), Snitching: Criminal Informants and the Erosion of American Justice (New York University press), p.177.

${ }^{14}$ Russell D. Covey (2014), ‘Abolishing Jailhouse Snitch Testimony', Wake Forest L. Rev. Vol.49, p. 1375.

${ }^{15}$ Alexandra Natapoff (2004), 'Snitching: Institutional and Communal Consequences', Legal studies paper No. 2004-24, p. 652.
} 
past crime they participated i.e., co-participants after the fact. Thus, it does not cover active criminal informants, i.e., it does not include the most controversial arrangement made with undercover agents or confidential informants, who infiltrate a crime and are often active in the commission of a crime. Nor does it cover jailhouse informants, who often claim to have received incriminating information or confession from a suspect or a defendant while incarcerated together.

\section{The Rationale for Criminal Informant Use in Ethiopia}

This section attempts to explore and examine the rationales advanced in favour of criminal informant use in the Ethiopian criminal justice system. Thus, the point of departure would be the criminal justice policy; then the respective laws that embrace criminal informants are consulted.

\subsection{A matter of necessity}

The need to investigate and prosecute organized crimes, which are mainly beyond ordinary means of investigation, is among the major rationales for jurisdictions to have recourse to criminal informant use. ${ }^{16}$ Ethiopian policy makers also subscribe to this rationale. With a view to combat and prosecute serious and complex crimes, the criminal justice policy embraces special investigative techniques such as, criminal informant use, physical and/or electronic surveillance, informant protection schemes, and undercover agents. ${ }^{17}$ The underlying assumption behind such special investigative tools rests on the fact that ordinary means of investigation are not effective in detecting, investigating and prosecuting the crimes under consideration. It is often suggested that the veil of secrecy and the intermediary features of organized crimes necessitate such extraordinary techniques of investigation. ${ }^{18}$ Inducing criminal informants with lenient treatments in terms of charge or sentence or with immunity has been found necessary to detect and effectively prosecute such crimes. However, the policy seems to expand the use of criminal informants beyond organized crimes and includes complex and serious crimes provided that the ordinary means of investigation is unable to solve such crimes. $^{19}$

The necessity rationale is also used to validate the use of criminal informants in the prosecution of crimes of trafficking and smuggling in persons in Ethiopia.

\footnotetext{
${ }^{16}$ R. Michael Cassidy (2004), “'Soft Words of Hope': Giglio, Accomplice Witnesses, and the Problem of Implied Inducements”, Northwestern University Law Review, Vol. 98, p. 1137; Alexandra Natapoff (2009), supra note 13, p 30.

${ }^{17}$ See The ECJ Policy, supra note 12, section 3.17, p 20.

${ }^{18}$ R. Michael Cassidy (2004) supra note 16; Alexandra Natapoff (2009), supra note 13.

${ }^{19}$ See The ECJ Policy, supra note 12, section 3.17.5 (a \& b), p. 22.
} 
The drafters of this law take the unavailability of evidence as a rationale to resort to criminal informant use-as a matter of necessity. ${ }^{20}$ Likewise, in practice, prosecutors point to the impossibility of obtaining evidence (in particular that of witnesses) as one major reason to vindicate informant use. ${ }^{21}$ Thus, instead of 'risking no punishment at all' on all criminal participants, it is better to punish more culpable defendants or impose some of the punishment offenders deserve by flipping less culpable ones. This goes to the notion of utilitarian calculus of costs and benefits that can be captured by the famous adage: Half a loaf is better than none. J. Bentham once noted:

... so long as there is other means of obtaining the conviction of a criminal without thus rewarding an accomplice, this method is bad; the impunity necessarily accompanying it is an evil. But if there be no other means, this method is good; since the immunity of a single criminal is a less evil than the impunity of many. ${ }^{22}$

It should be noted that the instrumentality of criminal informants is not something uncontested. There are concerns that the use of informant testimony, by tolerating and at times by generating some crimes, could be counterproductive in the fight against crimes. ${ }^{23}$ It has also the potential to reduce the deterrent effect of punishment. ${ }^{24}$

\subsection{Efficiency}

Although it is nowhere explicitly mentioned as a justification for informant use in Ethiopia, it is generally acknowledged that criminal informants deliver efficiency benefits to any justice system by making investigation and prosecution activities easier and cheaper. ${ }^{25}$ It spares time and resources which otherwise would be consumed in the investigation and prosecution of crimes. Thus, the rationale focuses on the saving of time and resources regardless of whether informant use is a matter of necessity. Thus, so long as the use of criminal informants delivers efficiency, it may displace ordinary means of investigation that are capable of unveiling the crime. Indeed, Ethiopian justice actors point to this rationale while employing criminal informants even in the

\footnotetext{
${ }^{20}$ Explanatory Note on the Anti-trafficking and Smuggling in Persons Proclamation, on file with the author (contains no page).

${ }^{21}$ Alemu Meheretu (2018), Exploring Criminal Informant Use in Ethiopia: Some Experiences from the Federal Government and Selected Oromia Zones, (unpublished), p.18.

22 J. Bentham (1968), The Rational of Rewards in Works, edited by J. Bowring, Vol. 2, p. 223.

${ }^{23}$ Alexandra Natapoff (2004), supra note 15, p. 661.

${ }^{24}$ Miriam Hechler Baer (2011), 'Cooperation's Cost', Wash. U. L. Rev. Vol. 88, p 903.

${ }^{25}$ Alexandra Natapoff (2009), supra note 13, p. 31; David Leimbach (2009), 'Minimizing the Risk of Injustice in cooperation Agreements', Dartmouth L.J, Vol.7, p.176.
} 
absence of any law authorizing them to do so. ${ }^{26}$ Surely, some invoke the Cassation ruling in Yordanos Abay vs. Public Prosecutor ${ }^{27}$, which sanctions the use of criminal informants reasoning that no law prohibits such use. In so doing they attempt to paint the practice some sort of formality, the propriety of which shall be discussed later.

While it is true that criminal informant use enhances the efficiency and effectiveness of the criminal justice process, it is laden with considerable risks and compromises of other sacred values of the justice system, namely accuracy and fairness. Researches document that the informant system is compounded with host of adverse effects including perjury and wrongful convictions ${ }^{28}$, corruption and abuses ${ }^{29}$, discrimination against similarly situated defendants ${ }^{30}$, and impunity. ${ }^{31}$ Most of these concerns do not seem to be jurisdiction specific, and are thus valid for Ethiopia too. What is less certain would be the extent to which they apply to Ethiopia, which needs further research. ${ }^{32}$

\footnotetext{
${ }^{26}$ Alemu Meheretu, supra note 21, p.18.

${ }^{27}$ Yordanos Abay vs. Public Prosecutor, Federal Supreme Court Cassation Decision, Vol. 12, File No.57988, Tir 10, 2003, p. 196.

${ }^{28}$ Brandon L. Garrett (2008), 'Judging Innocence', Colum. L. Rev. Vol.108, pp. 76, 87-88 (noting that out of 200 DNA exonerations 18 percent are caused by false informant testimony); S. Greer, 'Where the Grass is Greener? Super grasses in Comparative Perspective', in R. Billingsley, et al (2001) (eds) Informers, Policing, Policy and Practice. (Devon: Willan Publishing); Bennett L. Gershman (2002), 'Witness Coaching by Prosecutors', Cardozo L. Rev. Vol. 23, pp., 852-53; R. Michael Cassidy (2004), supra note 16, p.1130. ; Nicholas Fyfe and James Sheptycki (2006) supra note 2, p.34.

${ }^{29}$ R. Michael Cassidy (2004), supra note 16, p.1130; Alexander J. Menza (1999), 'Witness Immunity: Unconstitutional, Unfair, Unconscionable', Seton Hall Const. L.J. Vol.9, p.532; Alexandra Natapoff (2004), supra note 15, p 663.

${ }^{30}$ Stephen J. Schulhofer (1993), 'Rethinking Mandatory Minimums', Wake Forest L. Rev. Vol. 28, pp. 211-12 (criticizing cooperation for causing paradoxical disproportionalities in sentences); Alexandra Natapoff (2004), supra note 15, p.664; Alexander J. Menza (1999), supra note 29, p 531. (Arguing that granting witness immunity in exchange of testimony results in unequal enforcement of the laws).

31 Daniel C. Richman (1996), 'Cooperating Defendants: The Costs and Benefits of Purchasing Information from Scoundrels', Fed. Sent'g Rep. Vol.8, p.293; Alexandra Natapoff (2009), supra note 13, p.38; Nicholas Fyfe and James Sheptycki (2006), supra note 2, p.347.

${ }^{32}$ For a review of the challenges from the Ethiopian context, see Alemu Meheretu, 'The Challenges of Using Criminal Informant Testimony in Ethiopia', Journal of Ethiopian Law, Forthcoming.
} 


\section{The Legal Framework on Criminal Informants}

The use of criminal informants, which permeates any crime in practice $^{33}$, is largely unregulated in Ethiopia. The exception could be crimes of corruption, trafficking and smuggling in persons and terrorism where its application is formally sanctioned in general terms. Yet, there are no detailed procedures governing it. Although the use of criminal informant remains -for the most part- unregulated, ${ }^{34}$ some argue that the Federal Cassation Division in Yordanos Abay vs. Public Prosecutor case ${ }^{35}$ sanctions it; and indeed prosecutors often successfully invoke this case as an authority.

The authority of this case, which upholds the switching of an accused involved in a crime of theft into a witness against another co-accused, in return to a concession (dropping of charges) is problematic. To start with, by holding that no law prohibits the prosecution from turning suspects -against whom criminal investigation has been completed- into a witness, the court erroneously displaces a clear law that proscribes any inducement against suspects. ${ }^{36}$ Criminal informant selection involves inducing a suspect with an offer of immunity at the investigative stage or later on the basis of his statement given at the police station. ${ }^{37}$ Further, by articulating no standard that can guide informant use, the court leaves the gate wide open so much so that defendants are turned into witnesses at the last minute of the trial including after the prosecution witnesses are heard, which is not uncommon in practice. ${ }^{38}$

Leaving the discussion on the dynamics of the practice for another work (which is worth a separate discussion), this article deals with the sufficiency or otherwise of the legal framework on criminal informant focusing on the regulation of standards for selection, the concessions and benefits involved, enforcement mechanisms, and the safeguards put in place for defendants. To some extent, resort will be made to the practice so as to support the legal analysis.

\subsection{The FDRE Criminal Justice Policy}

The 2011 FDRE Criminal Justice Policy embraces criminal informant use as one policy option to combat complex and serious crimes including organized

\footnotetext{
${ }^{33}$ Alemu Meheretu, supra note 21, p. 49.

${ }^{34}$ Id., p. 49 and Alemu Meheretu, supra note 32.

${ }^{35}$ Yordanos Abay vs. Public Prosecutor, supra note 27.

${ }^{36}$ Article 31 of the Criminal Procedure Code reads: "No police officer or person in authority shall offer or use or make or cause to be offered, made or used any inducement, threat, promise or any other improper method to any person examined by the police."

${ }^{37}$ Alemu Meheretu, supra note 21, section 4.1.

${ }^{38}$ Ibid; see also Alemu Meheretu, supra note 32.
} 
crimes, crimes involving use of firearms and terrorism. ${ }^{39}$ Although the Policy lists the above crimes, it seems to validate criminal informant use in complex and serious crimes on the condition that the cooperation of the informant must be so essential that effective investigation or prosecution is impossible or becomes taxing without it. ${ }^{40}$ The merit of this expansive approach on informant use -which is apparent both from the range of crimes the phrase 'serious and complex crimes'- covers and the second limb of the qualification i.e., '... becomes taxing', is open to debate. This would leave the gate wide open to the detriment of thorough and effective investigation for it may encourage laziness of the investigators. It could also adversely affect defendants prosecuted based on informant testimony. 41

To some extent, the first caveat that emphasizes on the 'impossibility' requirement would render criminal informant use an option of last resort. Thus, where ordinary means of investigation can deliver the evidence needed to prosecute the crimes under consideration, criminal informant use is not permitted. Perhaps, this would be something easier said than done as it is difficult to sanction the exhaustion of all ordinary means of investigation.

The policy envisages relevant laws to regulate the use of criminal informants. Although the Draft Criminal Procedure Code explicitly mentions criminal informants after the fact, it has limited the scope of special investigative techniques -active criminal informants (under covers) being one of them- only to organized crimes such as money laundering, corruption, trafficking in persons, and terrorism. ${ }^{42}$

\subsection{The anti-corruption laws}

The anti-corruption laws (in particular, Proclamation No. 434/2005, and Proclamation No. 881/2015) recognize criminal informant as one law enforcement tool. But these proclamations do not define the concept in the context applied in this article. A related Proclamation issued to amend Proclamation No. 434/2005 (i.e., Proclamation No. 882/2015) contains a generic definition of the word 'informant" ${ }^{\text {"3 }}$ to refer to law-abiding innocent persons or officers who supply information to law enforcement organs. As shown in section one above, however, this concept is quite distinct from criminal

${ }^{39}$ The ECJ Policy, supra 12, p 22-23. (Translation mine)

${ }^{40}$ Ibid.

${ }^{41}$ See generally Alemu Meheretu, supra note 32.

42 See Articles 88-94 of the Draft criminal Procedure Code (as was valid in June 2019).

${ }^{43}$ Article 2(2) contains the following definition: 'Informant' means any person who provides information, when he believes that corruption offences are committed, to appropriate organs or justice organs ... includes an auditor who audits matters relating to offences of corruption... and anyone who inspects and investigates such offences. 
informants per se which connotes suspects or defendants who provide evidence against fellow offenders in return to some concessions. This section examines the manner and the extent to which the law regulates the use of the latter, i.e., criminal informants in crimes of corruption. The following themes are identified for such an exercise throughout the article: standards of informant selection, concessions and benefits, safeguards for defendants and enforcement mechanisms.

\subsubsection{Standards for selection}

The Anti-Corruption Special Procedure and Rules of Evidence Proclamation and Corruption Crimes Proclamation relieve a criminal informant from any criminal liability on condition that he provides substantial evidence as to the offence and the role of his partners before the case is taken to the court. ${ }^{44}$ Thus, the suspect's /defendant's willingness to provide any relevant evidence may not out rightly qualify him/her to benefit from the available concession which is immunity. Two cumulative conditions/standards are attached to the concession/benefit: the weight of the evidence he/she furnishes and the timing the assistance is given. Only supply of substantial evidence at an appropriate time makes a criminal informant eligible to the concession. Evidence is said to be substantial and entitles immunity where ${ }^{45}$ :

a) It is sufficient to bring conviction by itself; or

b) It serves as a basis to lead to other evidences; or

c) Corroborated with other evidence, it is sufficient to bring conviction, and its absence makes conviction unlikely.

Of the above requirements, sub-article (a) appears to be too theoretical. It is less practical to imagine that a testimony of an informant alone or perhaps any other piece of evidence produced by the informant alone will be sufficient to sustain a conviction in most corruption cases. Obviously, it needs to be corroborated with another evidence such as documents, audit reports, other witnesses or even another informant evidence, etc. Conversely, this requirement can create an impression that criminal informant evidence alone warrants a valid conviction, which is problematic given its inherent unreliability.

Two more points deserve discussion in relation to 'substantial evidence'. The first relates to the issue as to who determines the value of evidence /testimony which qualifies for immunity from prosecution. The language of the law seems

\footnotetext{
${ }^{44}$ See Article 43(1), The Revised Anti-Corruption Special Procedure and Rules of Evidence Proclamation, Proclamation No. 434/2005 (herein after the Revised Anti-Corruption Special Procedure Proclamation); See also Article 8 (1) and (2) of the Corruption Crimes Proclamation No.881/2015(which recognize informant use and give cross-reference to the Revised Anti-Corruption Special Procedure Proclamation regarding details).

${ }^{45}$ Article 43(2), The Revised Anti-Corruption Special Procedure Proclamation.
} 
to suggest that this power is reserved to the executive ${ }^{46}$ apparently with no judicial review mechanism put in place. This could risk the rights of the defendant and/or the criminal informant. The second issue relates to the time when the informant gets the immunity. Is it required that the evidence should actually bring in either of the results mentioned from (a)-(c) above? Evidently, a probability that either of the results will materialize is sufficient. This is clear from the timing requirement which demands the informant to provide evidence "before the case is taken to court." Thus, the executive may not withhold the immunity waiting until the informant testifies before court. Indeed, the law demands the former to issue a letter attesting the immunity granted. ${ }^{47}$

The second prerequisite for criminal informant use in corruption cases relates to timeliness, i.e., cooperation should be extended "before the case is taken to the court." This refers to the time before charge is instituted thereby restricting the domain of criminal informant candidacy only to suspects as opposed to the accused or defendants. The possible rationale for this could relate to fairness and efficiency considerations. In addition to protecting defendants, it would promote thorough and effective investigation, encourage prudent charging decision (whom to charge and whom to use as a witness), spare time and resources that would otherwise be utilized for investigation or search of evidence.

But what if the accused expresses his willingness to cooperate after charge is instituted or amidst the hearing of the prosecution evidence, which is common in practice? While the law unequivocally refuses to recognize such assistance, the practice appears to be uneven. Some prosecutors insist that the appropriate time for cooperation is during the investigation stage or until the case is brought before court thereby rejecting any willingness to cooperate thereafter for it lacks legal backing and might involve a tactical move. ${ }^{48}$ On the other hand, others welcome any cooperation from criminal informants any time before the finalization of the hearing of prosecution evidence. ${ }^{49}$ The practice of the judiciary also reflects both trends. ${ }^{50}$ In one corruption case ${ }^{51}$ involving five defendants, the court endorsed prosecution`s move to withdraw charges against two of the defendants after its witnesses were heard. The prosecution was

\footnotetext{
${ }^{46}$ See Article 43(1) that grants such power to the then Anti-Corruption Commissioner (now transferred to the Attorney General by virtue of Proclamation No. 943/2016), and to appropriate organs vested with the power to investigate and prosecute corruption crimes. See Article 2(3), the Revised Anti-Corruption Special Procedure Proclamation.

${ }^{47} \mathrm{Id}$, Article 43(3).

${ }^{48}$ Alemu Meheretu, supra note 21, pp.37-39.

${ }^{49}$ Ibid.

${ }^{50}$ Ibid.

${ }^{51}$ Federal Prosecutor vs. Abebe Birhane and others, Federal High Court, File No. 203074, 30/06/2010 (Ethiopian Calendar).
} 
allowed to use such defendants as witnesses against the rest of the defendants on the ground that the issue is one of withdrawal and production of additional evidence pursuant to the Criminal Procedure Code which does not, as such, involve use of immunity from prosecution. Surely, apart from deflecting the issue, this is not in line with the timing requirement of the anticorruption law discussed above, which is the relevant and specific law to the case at hand. ${ }^{52}$ In another corruption case $\mathrm{e}^{53}$ involving three defendants, the court rightly rejected the prosecution's motion to switch one of the defendants into a witness on the ground that the motion jeopardizes the constitutional right to defence as the witness learns the defence strategy of his associates and other incriminating information on his associates while in prison; and this distorts the balance and fairness of the litigation.

The writer believes that the timing for cooperation should be regulated in such a way that the earlier the cooperation, the larger the benefits. The proscription that limits informant use to be before charging needs to be pushed forward. In so long as vital evidence can be obtained, prosecutors should accept cooperation extended any time before the hearing of prosecution evidence. This promotes efficiency and effectiveness and would not compromise fairness. However, distinctions of benefits should be made between those who cooperate at the earliest opportunity (during investigation) and those who waited until the hearing of prosecution evidence. For instance, for the latter, only sentence reduction may be considered which presupposes severance of the trial.

The foregoing discussion reveals that the law provides limited (only evidential and timing standards) and general standards for selection of criminal informants. Nonetheless, these are not the only relevant standards that should inform criminal informant selection. The anticorruption law overlooks other essential standards such as the degree of participation, the seriousness and complexity of the crime, the criminal record of the informant, the availability of other evidence, the accuracy and reliability of the evidence/testimony and the risks to the criminal informant. Thus, for instance evidence from less culpable informants accused of less serious crimes can be used to convict more culpable ones accused of serious crimes.

\subsubsection{Concessions and benefits}

Under the law, criminal informant use in crimes of corruption involves suspects trading evidence/information for immunity on condition that the above evidential and timing standards are met. It is interesting to see whether a criminal informant who does not satisfy the above requirements can get any

\footnotetext{
${ }^{52}$ For more discussion, see Alemu Meheretu, supra note 21 and 32.

${ }^{53}$ Federal Prosecutor vs. Getachew Walelign and others, Federal High Court, File No. 209610, 18/07/2010 EC.
} 
concession other than immunity (such as sentence reduction). Unlike, witness protection law, the Anti-Corruption law, does not expressly recognize other concessions for defendants. Short of immunity, for those who do not satisfy part of the above requirements, other concessions such as mitigation of sentences need to be available. For instance, those who fail to satisfy the timing requirement can be considered for other lenient treatments such as special sentence reduction; apart from those triggered by mitigating circumstances envisaged under the substantive law. However, this can only be achieved in a separate trial for one cannot be a witness against a defendant with whom he is charged and tried jointly. Perhaps it could also involve plea bargaining proper, in which case the defendant may benefit from charge or sentence concessions, as the case may be.

One may also wonder whether immunity is granted horizontally to any criminal informant who provides substantial evidence without considering the seriousness of the crime and the degree of participation and culpability of the informant and that of the defendant against whom evidence is sought. Ostensibly, absence of such factors under the law suggests that this can be the case. Nonetheless, this is problematic and would defeat the very purpose of using criminal informants, where seriousness of the crime and degree of participation are key factors; hence the adage: using a small fish to catch the bigger ones. It will not promote the purposes of punishment, either.

Another benefit that could be available to criminal informants relates to protection measures. Apart from the witness protection proclamation, this is evident from the power of the Anti-corruption Commission to extend protection to witnesses and whistle blowers pursuant to the law ${ }^{54}$, which is now transferred to the Attorney General. A criminal informant qualifies as a 'protected person' within the meaning of the relevant law i.e., Witness Protection Proclamationwhere three conditions are met, namely, those which relate to the seriousness of the offence, the value of the evidence produced, and the threat of danger the informant faces. ${ }^{55}$ Such criminal informants may benefit from the protection measures available under the Proclamation which generally include protection of anonymity, immunity, protection from retaliatory measures, providing remedial measures when retaliation occurs, and counselling services. ${ }^{56}$

However, conflating the anti-corruption law with the witness protection proclamation raises many issues. The disparity of conditions attached to the concessions in the two proclamations complicates the application of such

\footnotetext{
${ }^{54}$ Article 7(8), The Revised Federal Ethics and Anti-Corruption Commission Establishment Proclamation No.433/2005.

${ }^{55}$ For detailed discussion of such conditions, see Section 3.5 below.

${ }^{56}$ For the complete list of such measures, see Article 4(1)(a) through (t) of the Witness Protection Proclamation.
} 
measures. A case in point is immunity, the invocation of which involves disparate conditions under the two laws. ${ }^{57}$ This deadlock can be temporarily resolved by limiting the applicability of conditions under the anticorruption law for immunity purposes while the conditions under the witness protection law apply to protection measures other than immunity.

Another issue relates to whether pecuniary related concessions could be the subject of an informant deal. The Revised Anti-Corruption Special Procedure Proclamation (as amended by Proclamation No. 882/2015) seems to have excluded pecuniary concessions connected to the crime in informant deals. ${ }^{58}$ Thus, a criminal informant should pay back the benefits he derives from the crime of corruption. However, an informant who is involved in bribing a person for a service he is otherwise entitled to obtain lawfully, is allowed to get back the amount he has put for bribing, from the proceeds of the crime upon disclosing such bribe. ${ }^{59}$ This seems to motivate such informants to come forward and expose more culpable persons without fear of being prosecuted of bribing.

Other pecuniary benefits unrelated to the crime of corruption could be available to criminal informants. Thus, pecuniary benefits recognized as protection measures under the witness protection proclamation such as per diems and transport allowances, medical treatment for injuries caused by retaliatory measures, arrangement of employment and education opportunities, etc. could apply to criminal informants, as appropriate. ${ }^{60}$

The anti-corruption proclamation embodies a general protection clause that evidence acquired from a criminal informant will not be used against him. ${ }^{61}$ Yet, the language of the law under Article 43, Sub-Articles (3) \&(4) of Proclamation No. $434 / 2005$ creates an impression that this protection is limited to suspects to

\footnotetext{
${ }^{57}$ For more discussion on this, see Sections 3.2 and 3.5.

${ }^{58}$ See Article 43(6) of Proclamation No. 434/2005 and Article 34 of same Proclamation as amended by the Revised Anti-corruption special procedure and Rules of Evidence (Amendment) Proclamation No. 882/2015.

Article 34(1) of the Proclamation provides: "The defendant shall return the property acquired by the commission of the crime and the benefit derived from the property or the amount equivalent to it or the amount equivalent with the damage sustained by the commission of the crime."

${ }^{59}$ Article 8 (3) of Corruption Crimes Proclamation No. 881/2015 reads: "The bribe, gift or valuable thing a person has given in consideration for service he has lawfully obtained or is entitled to obtain shall be restored to him out of the property forfeited to the state on account of the crime, where he has disclosed his act of giving such an advantage."

${ }^{60}$ For more discussion on the requirements and the available protection measures, see sections 3.5 below.

${ }^{61}$ See 43(3), The Revised Anti-Corruption Special Procedure Proclamation.
} 
whom immunity is granted under Sub-Article 3; while apparently leaving out suspects whose immunity is revoked under Sub-Article $4 .^{62}$

As a rule any statement made or evidence disclosed in connection with informant agreement negotiation or included in the agreement should not be used against the criminal informant regardless of the outcome of the agreement. This, in addition to motivating potential informants to cooperate, promotes fairness to the defendant who provides or agrees to provide evidence in anticipation of concessions from the state. This rule needs to be reflected under the anti-corruption law. However, some necessary caveats should be made to the effect that the informant may not, for example, invoke the protection against perjury or misleading of justice charges.

Another issue that deserves some reflection is whether the protection clause extends to civil lawsuits against a criminal informant. Although this, in principle, depends on the nature of immunity granted to the informant, the contextual reading of Article 43 of Proclamation No. 434/2005 titled "immunity from prosecution", and the unequivocal exclusion of the proceeds of the crime from the subject of the informant agreement suggest that the protection clause is limited to criminal responsibility. Surely, the privilege against self-incrimination, which triggers the protection clause, does not apply to civil matters. Thus, arguably, any evidence obtained in relation to the informant deal may be used for civil lawsuits by the government. The concession due to the informant i.e., grant of immunity is apparently contingent upon his agreement to return the proceeds of the crime.

\subsubsection{Safeguards for defendants}

The Anti-corruption law does not provide adequate protection for defendants prosecuted based on informant testimony against risks such as unreliable or wrongful conviction and other concerns of unfairness. From the reading of the anti-corruption law, one may take the timing requirement, which discourages the late use of criminal informants, as a guarantee for the defence and the 'fair' use of criminal informants.

However, in the main, common safeguards ${ }^{63}$-such as legal counsel (mandatory legal representation), the right of disclosure (of the cooperation agreement and other culpable and exculpable evidence), liberal cross

${ }^{62}$ Sub-Articles 3 and 4 of Article read as follows:

(3) Where the suspect is given immunity, the appropriate organ shall certify it in writing. The appropriate organ may not use the evidence acquired in accordance with this Article against the suspect.

(4) Where the suspect fails to provide the evidence or give testimony according to the agreement, the decision to give immunity shall be revoked.

${ }^{63}$ For more discussion on this, see Alemu Meheretu, supra note 21, section 4.4. 
examination covering matters beyond subjects of examination-in-chief (for example such details relevant to test informant's credibility as his criminal record, the nature of concession he obtains from the prosecution, etc.), evidence corroboration requirements, and enhanced judicial review on the selection, admissibility, weight of the informant testimony- are lacking or scanty at best. On the contrary, the Proclamation attaches equal weight to the testimony of criminal informants and ordinary witnesses; and it demands justice actors to treat these categories of testimony alike. ${ }^{64}$ The merit of this rule is open to doubt. It could discourage justice actors from approaching criminal informant testimony with suspicion and review it with extra caution having regard to its inherent proneness to unreliability. It would rather invite them to attach undeserved weight to such testimony to the detriment of accurate outcome/verdict.

\subsubsection{Enforcement mechanisms}

While criminal informant use presupposes the conclusion of a formal agreement between the prosecution and the suspect, there is no formal agreement required by law; ${ }^{65}$ nor is it concluded in practice. ${ }^{66}$ The anti-corruption law merely requires the Attorney General (which was formerly the power of the anticorruption commissioner) to certify the immunity granted to the informant in writing. ${ }^{67}$ Nor are there any clear enforcement mechanisms of the agreement stipulated by law. Prosecutors seem to have superior leverage to enforce the deal than criminal informants. The use of leading questions to manage informants who turn hostile ${ }^{68}$, the threat to vacate the immunity and pursue charges of perjury or misleading justice ${ }^{69}$, as appropriate, provide prosecutors a strong leverage against any breaches of agreement by the informant.

In contrast, the suspect or defendant-turned informant remains at the mercy of the prosecution and lacks meaningful enforcement mechanism. Perhaps, in principle they may challenge the decision of prosecutors administratively or before court using immunity certification letter, if granted. However, this is easier said than done. First, in the absence clear enforcement mechanism, the

${ }^{64}$ See Article 43(5), The Revised Anti-Corruption Special Procedure Proclamation, which reads: The testimony of the person who has been given immunity from prosecution shall have equal weight as the testimony of ordinary witness.

${ }^{65}$ Article 43(4) speaks of 'agreement'. The close reading of the provision suggests that this is not a formal agreement rather a generic term used to indicate the informant's commitment to cooperate which can be expressed orally.

${ }^{66}$ Alemu Meheretu, supra note 21, p.69.

${ }^{67} \mathrm{See}$ 43(3), The Revised Anti-Corruption Special Procedure Proclamation.

${ }^{68}$ Article 44 of the Revised Anti-Corruption Special Procedure Proclamation authorizes prosecutors to use leading questions upon obtaining the permission of the court.

${ }^{69}$ See Article 446 of the 2004 Criminal Code of Ethiopia. 
prosecution may easily evade or delay it until evidence is furnished thereby leaving criminal informants vulnerable. Second, the decision to grant, deny, withhold or revoke immunity is not subject to judicial review.

It is possible for a prosecutor to receive the information and refuse to honour his/her promises unless he/she is concerned with its repercussions on informant's future cooperation. While this problem would be quite pronounced in the informal criminal informant use, it also at times occurs in crimes of corruption where guarantees are provided by law to the effect that evidence obtained from the informant cannot be used against him. ${ }^{70}$ In one corruption case, ${ }^{71}$ a criminal informant led to all co-offenders in exchange of promise of immunity for his/her own crimes. But, the prosecutor withdrew the promise and pressed a charge on three counts to have the defendant convicted who was eventually sentenced to 18 years of imprisonment. Although, the reasons were not clear, the defendant's huge involvement in the crime might be the possible explanation. If that was the case, the prosecution should have investigated the case further, to at least know the degree of the informant's involvement and identify the right candidate before making any promise or agreement with the informant. Although this case may not capture the entire picture, -which warrants generalization- it can illustrate the potential for prosecutorial renege on promises, which is not acceptable by any standard -both from the interests of the government and that of the individual defendant. This renege offends principles of fairness; it also contradicts the very objective of informant agreement -by eroding suspects' confidence on the prosecutor and discouraging future cooperation from other informants.

On top of absence of sanctions and enforcement mechanisms, the law does not articulate the role of the judiciary in the enforcement of the agreement. The court should be mandated to review the selection of criminal informants focusing on the standards used by the prosecution, and assess the reliability and weight of criminal informant testimony freely and thoroughly having regard to its inherent problems.

\subsection{The Anti-trafficking and Smuggling Proclamation}

The Prevention and Suppression of Trafficking in Persons and Smuggling of Migrants Proclamation No. 909/2015 (herein after the Anti-trafficking and Smuggling Proclamation), which is currently under review for amendment, embraces special investigative techniques and sources of evidence that are believed to be instrumental in combating the crime under consideration. Included among these are infiltrating criminal organizations, surveillance,

\footnotetext{
${ }^{70}$ Article 43(3), The Revised Anti-Corruption Special Procedure Proclamation.

${ }^{71}$ Alemu Meheretu, supra note 21, p 72.
} 
interceptions, simulation (undercover), and criminal informant use. ${ }^{72}$ Leaving other investigative techniques and sources of evidence aside, this section briefly reviews the use of criminal informants as is recognized under the Antitrafficking and Smuggling Proclamation.

\subsubsection{Standards for selection}

Article 23 of the Anti-trafficking and Smuggling Proclamation -titled 'suspects [sic] immunity from prosecution'- sanctions criminal informant use and rewards a criminal informant with immunity or sentence reduction in return to the assistance he provides towards the prosecution of other criminal participants. However this is not unconditional. The Proclamation embodies three requirements:

The first precondition relates to evidence weight requirement. For a criminal informant to be eligible to the benefits attached to cooperation, he needs to furnish substantial evidence as to the crime and against co-participants. This requirement is the verbatim copy of the standard stipulated under the anticorruption proclamation discussed above in section 3.2. Thus, since the meaning of substantial evidence and the issues that arise in connection with it are similar, there is no need to discuss it here.

The second requirement refers to time requirement. A criminal participant's cooperation as a criminal informant must be made at the right time, i.e., before the case is taken to court. This is again similar with the requirement envisaged in the anti-corruption laws discussed earlier.

The third requirement is related with centralized decision-making regarding the selection of criminal informant. The mandate to select criminal informants from among criminal participants is not the responsibility of individual prosecutors. Rather it rests with the then Minister of Justice and now the Attorney General. This requirement, if taken only as a requirement of approval /a system of internal review, would help scrutinize potential errors, abuses and rooms for corruption. However, the reading of the provision suggests otherwise because the prosecution cannot use criminal informants unless instructed by the Attorney General. This violates the functional autonomy of individual prosecutors, and its practicality is open to doubt. Centralized personal decision by the Attorney General on the day-to-day routines/exercise of prosecutorial discretions such as selection of criminal informants is neither practical nor justifiable. That is why in practice, this has been delegated to department heads of the prosecution units. ${ }^{73}$ Thus, this requirement needs to be framed in such a way that the decision of prosecutors to select and reward criminal informant

\footnotetext{
${ }^{72}$ See Articles 18 and 23 of the Anti-trafficking and Smuggling Proclamation.

${ }^{73}$ Alemu Meheretu, supra note 21, p.42
} 
needs to be justified through the process of approval from supervisors/ department heads.

As with crime of corruption, the standards provided for selecting criminal informants in trafficking and smuggling in persons lack adequacy and clarity. However, to some extent the latter considers additional standards that relate to the degree of participation and the degree of harm victims suffer, albeit erroneously as shown below. Thus, immunity will be withheld for criminal informants whose crime results in the death of a victim or removal of his organs or exposure to incurable diseases. ${ }^{74}$ Instead, such informant will be eligible for sentence reduction. ${ }^{75}$

Other important standards such as the seriousness and complexity of the crime (apart from its impact on victims), the criminal record of the informant, the availability of other evidence, the accuracy and reliability of the evidence/testimony, the risks to the criminal informant, among others, are not expressly embraced under the law. Moreover, there are no internal guidelines that address these matters.

\subsubsection{Concessions and benefits}

As opposed to the first two requirements discussed above, one major departure of the Anti-trafficking and Smuggling Proclamation from other laws under discussion is that it embraces broad concessions, albeit vaguely worded. The concessions to criminal informants include partial or full immunity from prosecution or reduction of sentence. ${ }^{76}$ Conflating concessions entails complex questions of enforceability. The first problem relates to the meaning of partial immunity: Is it about 'charge bargaining' where one or either of the several counts is dropped in exchange for a testimony/evidence combined with a guilty plea? Or does it refer to use immunity (limited to the offence to the prosecution of which he supplies information) as opposed to transactional immunity (complete immunity covering any related transaction)? As the nature and scope of the concessions lack clarity, each interpretation has its own implications in terms of scope, nature, duration, effects, etc., of the respective obligations and benefits of the parties (the prosecution and the informant).

Another issue relates to the problems that accompany sentence reduction to criminal informants. Although plea bargaining and informant use may overlap and operate concurrently, this is not regulated properly. Some of the relevant stipulations are not in tune with the purposes of negotiated justice in general and the rationales of criminal informants use, in particular. Such issues abound on

\footnotetext{
${ }^{74}$ See Article 23(2) of the Anti-trafficking and Smuggling Proclamation.

${ }^{75}$ For more, see section $\mathrm{C}$ below.

${ }^{76}$ See Article 23(1) and (2) of Anti-trafficking and Smuggling Proclamation.
} 
the conditions attached to sentence reduction. ${ }^{77}$ While degree of participation is not expressly indicated as a requirement for total or partial immunity, it makes no sense to use it as prerequisite for sentence reduction. This is because; first, by definition the lesser the degree of participation, the lesser the punishment would be, ceteris paribus. It is simply redundant to mention degree of participation as one factor for sentence determination. Moreover, the requirement seems to suggest that those criminal informants having higher degree of participation do not deserve any sentence mitigation regardless of providing substantial evidence against others and pleading guilty of their own crimes. This stands in clear contrast to the essence of sentence bargaining which involves a defendant's justified expectation of some sentence reduction in return for pleading guilty. It also negates the rationale of criminal informant use.

Therefore, the requirement of degree of participation should rather be used as one precondition to reward criminal informants with immunity and its use in sentence rewards should be limited to determining the amount of sentence reduction; and not for eligibility purposes as such. So long as the informant provides substantial evidence and pleads guilty to his own crime, he should be eligible for sentence reduction regardless of his degree of participation in the crime or any other condition such as victim's injury.

The other precondition to determine the nature of rewards to criminal informants concerns harms sustained by victims. The death of a victim, stealing of his organs, or contracting him incurable disease disqualify the informant from receiving immunity, and instead transforms the informant to be a candidate for sentence reduction depending on his degree of participation and the value of evidence he furnishes. ${ }^{78}$

It is interesting to note that the above factors are alternative. While this automatic exclusion of immunity is meant to protect victims of the crime and the public, it is likely to entail undesirable outcomes. By risking no prosecution at all, it can stand in contrast to the very purpose of employing criminal informant testimony: fighting the crime and protecting victims. There is no good reason to exclude immunity simply without connecting the suspect heavily with the above harms sustained by victims. So long as the suspect's degree of participation is low and he provides substantial evidence against more culpable participants, immunity should remain an option, albeit as a last resort.

77 See Article 23(2) of the Anti-trafficking and Smuggling Proclamation which reads: "Notwithstanding the provisions of sub-article 1 of this article, when the victim dies, his organ is removed or he is exposed to incurable disease, the suspect shall not be set free from prosecution; provided however, that depending on his participation and the usefulness of the evidence provided, his punishment shall be reduced."

${ }^{78}$ See Article 23(2) of the Anti-trafficking and Smuggling Proclamation. 
Unlike anti-corruption law, the Anti-trafficking and Smuggling Proclamation remains silent on whether pecuniary concessions connected to the crime can be subjects of informant agreement. This should be expressly excluded for it would discourage potential traffickers as well as abuses and corruptions in the law enforcement. With respect to pecuniary concessions unconnected to the crime, it stands to reason to claim that the Witness Protection Proclamation may apply. Thus, any criminal informant implicated with the crime of trafficking in persons and smuggling may avail himself of the protections available under the Witness Protection Proclamation, including pecuniary benefits provided that he complies with the requirements set out there. ${ }^{79}$

Similarly, the law provides no assurance to a criminal informant that prohibits the use of his statements or the evidence he has disclosed -in connection with the informant agreement- against him. This discourages informant cooperation and could leave criminal informants in uncertainty, and thus needs legal intervention.

\subsubsection{Safeguards for defendants}

Like defendants in crimes of corruption, defendants who are prosecuted on charges of trafficking and smuggling in persons based on informant testimony lack special protections which duly consider the inherent problems of criminal informant use; notably unreliability of the testimony. The following protections are absent or at least are not explicitly embraced by law: ${ }^{80}$

- mandatory legal counsel to the defendant against whom informant evidence is used,

- the right of disclosure (i.e., to have access to the cooperation agreement and other culpable and exculpable evidence so that the defendant can test the credibility of informant evidence),

- liberal cross examination (which goes to matters beyond the scope of examination-in-chief and accommodates relevant impeachment materials including antecedents of the informant, the concessions received, etc.),

- evidence corroboration requirements (a requirement that informant evidence should be corroborated), and

- enhanced judicial review on the selection, admissibility, and weight of the informant testimony.

\subsubsection{Enforcement mechanisms}

The general problems of enforcement discussed above in the context of crime of corruption are also valid here. At times the problems are even more pronounced

\footnotetext{
${ }^{79}$ For discussion on the requirements and the available protection measures, see Section 3.5 below.

${ }^{80}$ For detailed discussions, see Alemu Meheretu, supra note 21, Section 4.4.
} 
with regard to the law on anti-trafficking and smuggling in persons. For instance, if one looks at the basis for enforcement of informant agreement, the law envisages neither a formal contract nor an official letter certifying its existence. This complicates enforceability. Sanctions on reneges such as exclusion of informant testimony in the event of collapse of the agreement, specific performance as appropriate, and other remedies if parties fail to discharge their commitments, are not recognized by law.

Apart from that, specific problems also abound. A case in point is the enforceability of sentence reduction, which as it stands now, is uncertain and unclear: Is it contingent upon delivery of the testimony or information? If so, is it dependent on the outcome of the trial? What guarantees are available for the defendant against possible reneges? What is the role of the court? All these remain dubious and involve complex issues of fairness, accuracy and efficiency. Perhaps viewing sentence reduction either as simple mitigation due to extenuating factors or a special sentence reduction triggered by both plea bargaining and cooperation agreement can help address some of these impasses.

The first approach is like ordinary cases where the prosecution ${ }^{81}$ or defence may raise mitigating factors (substantial assistance and lesser degree of participation, conditions attached to sentence reduction in the proclamation under consideration) so that the court mitigates punishment following general rules of mitigation. However, this approach is less feasible for it makes sentence reduction, which overlaps with sentence mitigation (envisaged under the substantive law) redundant.

The second approach, which is a feasible one, presupposes both plea agreement and informant/cooperation agreement between the prosecution and the informant whereby the latter not only pleads guilty but also supplies substantial evidence in exchange of sentence reduction, which the court will review and approve. Determining whether the threshold of substantial assistance is met would be within the prosecution's remit subject to judicial review, and should not depend on the outcome of the trial since it may encourage false testimony. On the other hand, the court will determine the validity of the guilty plea. The Proclamation needs to regulate all the above issues.

\subsection{The Anti-Terrorism Proclamation}

Article 33 of the Anti-terrorism Proclamation No. 652/2009 authorizes courts to treat cooperating defendants/criminal informants leniently. To benefit from lenient punishment, a defendant is expected to plead guilty with repentance or disclose the identity of other co-offenders. Here, the law combines plea

\footnotetext{
${ }^{81}$ Note that Article 149(3) of the Criminal Procedure Code authorizes the prosecution to raise mitigating circumstances.
} 
bargaining proper with criminal informant use when it demands the defendant to plead guilty or to disclose the identity of other participants in order to benefit from the available concessions.

Criminal informant use in the context of the anti-terrorism law is unique in three senses: First, unlike other laws discussed above, neither the provision of information against crime mates nor the weight of the information is mandatory to get the benefits of cooperation. What is expected of the informant is to plead guilty of his own crime with remorse or simply expose others. It is interesting to note that pleading guilty and exposing others are alternatives, not cumulative requirements. Thus, in theory a defendant/an informant may receive concessions in three scenarios: exposing others of crimes of terrorism; pleading guilty with repentance and explaining the details of his/her own crime, and doing the combination of the two.

In relation to the requirement of pleading guilty with repentance, the daunting task of forging a nexus between guilty pleas and repentance/remorse need some discussion. Since guilty pleas could be tendered for other motives extraneous to remorse (such as tactical reasons), it is quite difficult for the concerned organs (the prosecution and the court) to read the defendants' psyche and determine whether a given guilty plea truly involves repentance.

Further, what is less clear is the degree of cooperation required from the criminal informant. What does the phrase 'disclose the identity' of other criminal participants mean under Article $33 ?^{82}$ Is there any requirement for such an informant to testify against fellow participants or is it just enough for him to identify and name fellow suspects? The apparent reading of the provision seems to suggest the latter. However, as a matter of pragmatism it is likely to be the case that the criminal informant may assume a dual status: as a defendant for his own crime and as a witness against other fellow participants. This dual status would raise procedural issues on how to proceed with each case without one compromising the fairness of the other, which triggers among others severance of the trial.

Second, unlike its counterparts, there is no requirement of timing expressly indicated under the anti-terrorism law. While other proclamations demand that the assistance of the criminal informant should come before the institution of a charge, the anti-terrorism law leaves this open. Thus, in principle such assistance can be given any time before judgment. However, such an expansive

\footnotetext{
82 The article reads: "The court may mitigate the punishment, upon a request made by the public prosecutor where the defendant repents about his act of committing any of the crimes mentioned under this Proclamation and cooperates in elaborating in detail the manner of the commission of the crime or discloses the identities of the persons who participated in the commission of the crime." (Emphasis added)
} 
construction of the timing would undermine the rights of the defence against whom the informant furnishes incriminating evidence and hence the fairness of the criminal process, to the detriment of the former. Indeed, one may argue that under the existing Criminal Procedure Code the right time for a defendant to enter plea, particularly to plead guilty (which is a requirement in criminal informant use in terrorism cases), would be when the charge is read out to him and asked by the court to enter a plea. ${ }^{83}$ Thus, any subsequent guilty plea should not be admitted, thereby excluding subsequent criminal informant use. That said, as a matter of law nothing explicitly prevents the court from admitting late guilty pleas. Indeed, courts do welcome late guilty pleas in practice. ${ }^{84}$

Third, the benefit a criminal informant draws is limited to mitigation of sentences as against immunities. Thus, regardless of the probative value of the information he may supply, and the contribution he may furnish in the prosecution of others, a defendant charged with terrorism may not benefit from immunity. Here, one might argue that so long as the criminal informant fulfils the conditions provided under the Witness Protection Proclamation ${ }^{85}$, he may qualify for immunity. Nonetheless, in the presence of specific exclusion by the special law (i.e., anti-terrorism law) this would be farfetched.

One may question the need for re-stating guilty plea generated sentence mitigation here, which is an established and already recognized factor in sentence determination under substantive criminal law. ${ }^{86}$ Perhaps, it only makes sense, if this is construed to mean that the lawmaker targets special sentence reduction to be effected upon the recommendation of the prosecution, other than the one already recognized by the substantive law, which in effect would involve sentence bargaining. Otherwise, it would be redundant.

This is not to suggest, however, that criminal informants in terrorism crimes are not entitled to receive other concessions and benefits. So long as they comply with the conditions laid down under the witness protection proclamation $^{87}$, they are by definition entitled to receive the procedural and substantive protections as well as pecuniary benefits listed under Article 4(1) of the Proclamation, ${ }^{88}$ other than immunity which is unequivocally excluded by the

\footnotetext{
${ }^{83}$ Articles 132 and 135 of the 1961 Criminal Procedure Code of Ethiopia.

${ }^{84}$ Alemu Meheretu (2014), Introducing Plea bargaining in Ethiopia: Concerns and Prospects (PhD thesis, University of Warwick, UK), pp.159-60.

${ }^{85}$ See section 3.5 below.

${ }^{86}$ See Article 82(1) (e) of the 2004 Criminal Code of Ethiopia.

${ }^{87}$ See section 3.5 below.

${ }^{88}$ Such protections include, hearing of testimony in camera or behind a screen, relocation, withholding or change of identity, and pecuniary benefits such as per diem and transport allowance, medical treatment for injuries flowing from retaliatory measures, counselling
} 
Anti-terrorism Proclamation. With the law requiring the forfeiture of proceeds of the crime of terrorism and the property of a terroris ${ }^{89}$, no pecuniary concessions connected with the crime are available for a criminal informant in terrorism crimes who only benefits from sentence reduction under the law.

Before concluding this section, it is important to briefly outline the guarantees available for co-defendants who are prosecuted based on informant testimony drawn from their fellow defendants. In addition to other guarantees discussed above, there should be special protections available for such defendants. These include the following:

- the two trials should proceed separately;

- where assistance is provided, the benefits to the criminal informant must not depend on the outcome of the other trial to which assistance is given; and

- any admission or guilty plea the informant tenders should not be used to the prejudice of a co-defendant unless it is disclosed as part of the informant deal.

\subsection{The Protection of Witnesses and Whistleblowers of Criminal Offences Proclamation}

The Protection of Witnesses and Whistleblowers of Criminal Offences Proclamation No. 699/2010 (herein after "Witness Protection Proclamation") stipulates several types of protection measures to witnesses, whistleblowers and their families. ${ }^{90}$ The Witness Protection Proclamation defines 'whistleblower or witness' as "a person who has given or agrees to give information or has acted or agrees to act as a witness in the investigation or trial of an offence". ${ }^{91}$ The word 'person' under this definition can be construed to encompass both a lawabiding innocent informant as well as a criminal informant.

As part of such protection schemes extended to witnesses and whistleblowers in return to providing information or testimony, one finds witness immunity. ${ }^{92}$ Thus, while witnesses who qualify for immunity under this law are criminal informants -co-defendants or suspects who might have been prosecuted for their

services, arranging education and employment opportunities, etc. For a complete list of the protection measures, see Article 4(1) of the Witness Protection Proclamation

${ }^{89}$ See Article 27, the Anti-terrorism Proclamation.

90 Article 2(2) defines protected persons as: "a witness, a whistle blower, or a family member of a witness of a whistle blower who has entered into a protection agreement with the ministry [of Justice]." To enter such an agreement and benefit from the protection measures the seriousness of the crime for whose prosecution the information is supplied, the essentiality of the information, the degree of threat of danger posed are prerequisites. See article 3 of Protection of Witnesses and Whistleblowers of Criminal Offences Proclamation No.699/2010. (Hereinafter "Witness protection proclamation").

${ }^{91}$ Id., Article 21.

${ }^{92}$ Id., Article 4(1) (f). 
own crimes-, other catalogue of protection measures primarily presuppose lawabiding persons who simply provide information or testimony. Nonetheless, this is not to suggest that such category of protection measures are mutually exclusive, instead as shown below they may apply in combination, as appropriate. $^{93}$

The protection/benefit of immunity is not available to all witnesses or whistleblowers - to all criminal informants in context of this discussion. The law provides for the following three standards as prerequisites for immunity ${ }^{94}$ :

\section{The seriousness of the crime}

The crime to the investigation or prosecution of which the information is supplied should be punishable with rigorous imprisonment of 10 or more years or death. ${ }^{95}$ Criminal informants can only be used for the investigation or prosecution of serious crimes punishable with 10 years and more. Thus, arguably, the seriousness of the crime the informant was involved and his degree of participation are not relevant in the selection of a criminal informant provided that his crime does not overlap with that of the defendant. Neither the complexity of the crime to be prosecuted, nor the reliability of informant information is recognized for selecting a criminal informant. These serious limitations and gaps of the law need intervention. For the purpose of this standard, the lower punishment range is irrelevant. The phrase "...without having regard to the minimum period of rigorous imprisonment" under Article 3 of the Proclamation makes it plain that what matters is the upper limit which must not be less than 10 years of imprisonment. ${ }^{96}$

\section{The absolute relevance of the evidence}

This standard relates to instances where offences cannot be detected or prosecuted in the absence of the informant's assistance. This requirement in effect makes the use of criminal informant a last resort. Thus, where it is possible to effectively detect or prosecute the crime without the informant's assistance, the law does not allow criminal informant use. On the other hand, compared to the threshold of substantial evidence required by the anticorruption and the anti-trafficking and smuggling proclamations discussed

\footnotetext{
${ }^{93}$ Id., Article 4(1).

${ }^{94}$ Id., Article 3 and 5.

${ }^{95}$ Beyond using the generic term 'serious crimes', the Criminal Policy goes further to name crimes in this regard. Included are "organized crimes", corruption, terrorism, complex crimes and crimes of rioting. See the ECJ Policy, supra note 12, pp. 22-23.

${ }^{96}$ The article reads: "The protection under this Proclamation shall be applicable with respect to testimony or information given or investigation undertaken on a suspect punishable with rigorous imprisonment for ten or more years or with death without having regard to the minimum period of rigorous imprisonment..."
} 
above, the witness protection proclamation, which employs a language ${ }^{97}$ : “...the offence may not be revealed or established by other means...", requires a higher standard that can be described as essential evidence requirement. Thus, for an informant to satisfy this requirement he must supply essential evidence that either reveals the offence or determines the successful prosecution of the offence-i.e., evidence in the absence of which the offence cannot be detected or prosecuted. It is important to note however that the executive determines the value of the evidence and the concessions attached thereto ex ante. It is not required that the evidence actually brings the intended outcomes.

\section{The degree of threat of danger the informant faces.}

This standard requires that a threat of serious danger to the life, physical security, freedom or property of the informant or his family be established. Although this standard is mainly relevant to extend other protection measures such as hearing of testimony in camera or behind a screen, relocation, withholding or change of identity, its validity to the determination of whether immunity should be granted to a criminal informant is open to debate. Thus, one may argue that where either of the above risks to the informant are established, procedural or substantive protection measures, should apply, as appropriate rather than excluding immunity.

Where the foregoing prerequisites are satisfied cumulatively, a witness or whistleblower may be immune from offences for which he supplies information. In this sense, the protection of immunity presupposes the participation of the witness or whistleblower in a criminal act. Thus, it is available only to cooffenders/participants in a criminal activity with a view to encourage them to come out and testify against their mates.

Apparently, the concessions and benefits available to a criminal informant under the witness protection proclamation seem to be limited to immunity. However, with the Proclamation recognizing the application of procedural and substantive protection measures in combination ${ }^{98}$, other concessions including pecuniary ones can be considered. Thus, in addition to such procedural and substantive protection measures as withholding of identity, hearing in camera, relocation, change of identity; the criminal informant may, as appropriate, benefit from the following pecuniary benefits: ${ }^{99}$ transport allowance and per diem when summoned to testify; relocation cost where ordered; medical treatment free of charge for injuries due to retaliatory measures; funeral

\footnotetext{
97 The relevant part of Article 3(1)(a) of the witness protection proclamation reads : “... where the offence may not be revealed or established by another means otherwise than by the testimony of the witness or the information of the whistleblower ..."

${ }^{98}$ See Article 4(1) of the Witness Protection Proclamation.

${ }^{99}$ Ibid.
} 
expenses and provision of pecuniary subsidy to family for death caused by retaliatory measures; assistance in securing job and education opportunity; and counselling services. One important caution appears necessary in combining protection measures, in that the application of such measures must consider the specific features of criminal informant evidence. For instance, the protection of anonymity should be limited to the possible minimum and be extended with adequate counterbalancing measures (such as corroboration requirement, and rigorous judicial scrutiny) since it may induce unchecked criminal informant evidence, which is inherently prone to false incrimination.

One the other hand, unlike the anti-corruption law, the witness protection proclamation provides no protection to a criminal informant that proscribes the use of his statements or any evidence he supplies against him. This would create disincentive for potential criminal informants. Nor does the Proclamation set forth adequate counterbalancing measures for defendants prosecuted based on the testimony of protected witnesses, ${ }^{100}$ including criminal informants. Conversely, Article 26 of the Proclamation provides that: "[t]he fact that a witness is entitled to protection in accordance with this Proclamation may not be invoked as a ground to diminish the credibility of his testimony." This utterly ignores the power of protection measures, in particular immunity, in generating unreliable evidence. ${ }^{101}$

Finally, it is worthwhile to reflect on the enforceability of criminal informant deal under witness protection law. Like other laws discussed above, the witness protection law is marred by lack of enforcement mechanisms. The law neither recognizes a formal agreement for granting immunity, which it does with other measures of protection, ${ }^{102}$ nor does it empower courts to enforce immunity agreements, if any. On the contrary, the Attorney General's decision on protection measures are not subject to judicial review. ${ }^{103}$ Moreover, while the law imposes specific obligations on the parties with respect to some protection measures as is the case with those from (g)-(k) of Article 4(1), ${ }^{104}$ it refrains from doing so with regard to immunity.

\footnotetext{
${ }^{100}$ For some discussion on this, see Alemu Meheretu and Awol Alemayehu, 'The Ethiopian Law on the Right to Confrontation', Bahir Dar University Journal of Law, forthcoming.

${ }^{101}$ On this particular blemish of informant evidence, see note 28 above; see also Alemu Meheretu, supra note 32.

102 See Articles 8 to 22 of Witness Protection Proclamation where a formal protection agreement is required in such protection measures as physical protection of persons and property, provision of secure residence including relocation, concealing identity or ownership, and change of identity.

${ }^{103}$ Id., Article 25.

104 Id., Article 11.
} 


\section{Conclusion}

In order to control crime, notably organized crimes, jurisdictions employ various investigative and evidence generating tools including the use of criminal informants. Ethiopia is not exception to this. The use of criminal informants has been recognized in four proclamations: the anti-corruption, the anti-terrorism, the anti-trafficking and smuggling, and the witness protection proclamations.

The three proclamations namely, the anti-corruption, anti-terrorism and antitrafficking and smuggling proclamations overlap with the witness protection proclamation on criminal informant use. This overlap, which is apparent on preconditions for criminal informant use and rewards available to them, creates considerable gaps and inconsistencies. For instance, unlike the witness protection proclamation, the anti- terrorism proclamation attaches no importance to the weight of evidence obtained from a criminal informant. Furthermore, while the former grants immunity to criminal informants, the latter is limited to sentence mitigation. There is also contradiction between the anti-corruption or anti-trafficking and smuggling proclamations with witness protection proclamation. A case in point is timeliness for criminal informant use. While the latter puts no time limitation for criminal informant use, both the anticorruption, anti-trafficking and smuggling proclamations restrict criminal informant use to operate only before the institution of criminal charge.

All these and similar gaps and inconsistencies need to be resolved by enacting a comprehensive and coherent law on informant use or by ensuring consistency among the dispersed laws. Tentatively, the use of rules of interpretation together with the "inapplicable law clauses' ${ }^{105}$ inserted in the respective proclamations would be of some help to enforce the laws.

Although the above proclamations have attempted to set out some standards for selecting and rewarding criminal informants, they are far from being clear, specific and complete. There are no detailed guidelines to inform and complement the standards. Relevant factors such as the degree of participation/culpability of the criminal informant, the seriousness and complexity of the crime (both that of the criminal informant and the defendant), the criminal record of the informant, the availability of other evidence, the reliability and completeness of the testimony/evidence obtained from the criminal informant, among others, are unduly overlooked. The timing requirement, which is not recognized across all proclamations covered in this article, is also fraught with circumventions. This would leave the practice

105 A similarly worded clause is found in the proclamations under discussion: "No law, regulation, directive or practice shall, in so far as it is inconsistent with this Proclamation, be applicable with respect to matters provided for by this Proclamation." 
amenable to arbitrary use, if not abuse of criminal informant use. Thus, a comprehensive set of standards on informant selection and reward is imperative.

The concessions and benefits envisaged are incomplete and inconsistent. While some of the laws such as the anti-corruption proclamation reward criminal informants simply with immunity excluding other concessions, the anti-terrorism proclamation refuses to recognize immunity. On the other hand, as shown under Section 3 above, the anti-corruption proclamation combines sentence reduction with immunity, but erroneously. Further, with the exception of the anti-corruption law, the laws are ambiguous on whether pecuniary benefits connected to the crime can form part of the informant deal.

In all of the proclamations examined in this article, enforceability issues compound criminal informant use. There is no requirement for formal agreement between the prosecution and the informant in all the laws. Perhaps, the requirement by the anti-corruption law to the effect that the Ministry of Justice (currently the Attorney General) issues a letter attesting the grant of immunity to an informant -albeit not an agreement as such-, can serve some evidentiary purposes. The witness protection proclamation does not require any formal agreement on protection of immunity. This complicates enforceability of informant deals; invites controversies and uncertainties on the nature, scope and effect of the deals, the respective obligations and entitlements of the parties, especially that of the criminal informant. This can breed arbitrary uses and abuses of the criminal informant system.

Informant deals lack sanctions and enforceability. In practice the threat of prosecution (both of the underlying crime, perjury and/or misleading of justice), withholding of a bail bond and sometimes detention until testimony is given, are used as enforcement arsenals for the prosecution. Ostensibly, the criminal informant has no remedies with the exception of an internal administrative recourse, which is not reliable. These need legal intervention.

Although the inherent unreliability and defects of criminal informant testimony warrants robust judicial guarantees and intervention, the proclamations do not clearly articulate the role of courts. As a matter of law, the court needs to be mandated to review the selection of criminal informants, the admissibility of informant testimony, and evaluate it with extraordinary caution and attach a deserved weight to it. Thus, the legal requirement under the anticorruption and witness protection laws that demands justice institutions to treat informant testimony as ordinary witnesses needs revision. Moreover, the antitrafficking and smuggling proclamation needs intervention because it confuses plea bargaining proper with informant use (cooperation agreements) and overlooks the indispensable role of courts to review and sanction the plea agreement.

The lawmaker seems reluctant to foresee the considerable menaces that accompany criminal informant use, which include perjury and wrongful 
convictions, corruption and abuses, discrimination, and impunity. Such reluctance is evident at least in two fronts. First, the laws under consideration fail to provide for relevant safeguards and measures that attenuate the flaws and risks of the informant system. Guarantees such as protection against false testimony, requirement of formal informant agreement, effective review mechanisms, disclosure, corroboration of informant testimony, and liberal cross examination, are absent or scanty at best. With the exception of the anticorruption law, the laws also fail to assure a criminal informant that any evidence he provides will not be used against him. This discourages potential informants from coming forward and would leave those who provide evidence in a state of uncertainty.

This should not, however, imply 'absolute' protection. One notable exception would be liability for perjury or misleading of justice whereby an informant may not validly invoke the protection. Second, the anti-corruption and witness protection proclamations stipulate explicit rules that seem to ignore the inherent unreliability of criminal informant evidence. The anti-corruption law, instead of setting forth reliable safeguards against the blemishes of the informant system, unduly treats criminal informant testimony as carrying equal weight like that of the testimony of ordinary witnesses. Likewise, the witness protection proclamation prohibits the invoking of the grant of witness protection measures -including immunity to criminal informants- to challenge and undermine the credit of such witnesses. This is antagonistic to any prudent screening of such inherently unreliable piece of evidence, perhaps to the detriment of accurate outcomes. 